\title{
MODEL PENDIDIKAN DALAM KELUARGA BERBASIS MULTIRELIGIUS
}

\author{
Hadi Pajarianto ${ }^{1}$, Natsir Mahmud ${ }^{2}$ \\ 1STKIP Muhammadiyah Palopo, ${ }^{2}$ UIN Alauddin Makassar \\ ${ }^{1}$ Kota Palopo, Sulawesi Selatan, \\ 2Jalan H. M. Yasin Limpo No. 36, Samata-Gowa, Sulawesi Selatan \\ Email: pajariantohadi@gmail.com¹, natsirmahmud@gmail.com²
}

\begin{abstract}
Abstrak:
Penelitian ini bertujuan untuk mengkaji model pendidikan dalam keluarga yang berbasis multireligius. Fokus kajian ini terdiri dari tiga hal: (1) menemukan latar pluralitas sosial keagamaan pada keluarga Muhammadiyah berbasis multireligius; (2) model pendidikan keluarga pluralis berbasis multireligius; (3) perilaku sosial keagamaan pada keluarga Muhammadiyah Pluralis. Jenis penelitian ini merupakan penelitian kualitatif dengan pendekatan fenomenologi. Pendekatan fenomenologi digunakan untuk mendeskripsikan fakta-fakta atau fenomena yang dilakukan oleh manusia baik individu maupun kelompok. Hasil penelitian diperoleh: (1) latar pluralitas sosial keagamaan pada keluarga Muhammadiyah di Tana Toraja dibentuk oleh faktor budaya dan agama; (2) pendidikan keluarga Muhammadiyah pluralis yang berbasis multireligius di Tana Toraja berlangsung dalam beberapa model, yakni: pluralis, protektif, dan konsensual cenderung protektif; (3) perilaku sosial keberagamaan diidentifikasi terjadi pada ranah sosial keagamaan, pendidikan formal, politik, dan ekonomi.
\end{abstract}

\begin{abstract}
:
This research aimed to study the educational model in a family which based on religious plurality. This research focused on 3 things; (1) finding the background of the social religious plurality in Muhammadiyah family based multireligions; (2) family educational model; (3) social behavior in pluralistic Muhammadiyah Family. Qualitative method with the phenomenological approach was applied to uncover the phenomena of human behavior both individuals and groups. This study found: (1) the background of Muhammadiyah family in Tanah Toraja was built by culture and religious factors; (2) the education of Muhammadiyah Family occured in some patterns, they were: plural, consensual, and consensualprotective; (3) the social religious behaviors occurred in socio-religious interaction, formal education, economy, and politics.
\end{abstract}

Kata kunci:

Pendidikan, Keluarga, Pluralis

How to Cite: Pajarianto, H., \& Mahmud, N. (2019). Model Pendidikan dalam Keluarga Berbasis Multireligius. Lentera Pendidikan : Jurnal Ilmu Tarbiyah dan Keguruan, 22(2), 254-266.

\section{PENDAHULUAN}

Indonesia adalah negara plural, multidimensi dan multireligi, ditandai adanya lebih dari tiga ratus etnis, setiap etnis memiliki budaya sendiri dengan menggunakan lebih dari dua ratus lima puluh bahasa (Zada, 2006). Selain diperkaya dengan agama lokal penduduknya, hampir semua agama mainstream berada di bumi nusantara ini 
(Maliki, 2010). Kemunculan setiap agama yang lahir dari lingkungan plural dan majemuk, akan membentuk dirinya sebagai respons dari pluralitas tersebut. Oleh sebab itu, pluralitas harus dipahami secara benar oleh masing-masing pemeluk agama agar tidak menimbulkan konflik dan disintegrasi sosial. Pluralitas agama sendiri merupakan keharusan yang harus dipahami oleh setiap masyarakat Indonesia karena kita hidup berdampingan dengan berbasis multireligius.

Pluralitas menjadi fakta sosial pada masyarakat Indonesia secara umum. Bangsa Indonesia merupakan entitas yang majemuk dan plural, baik dilihat dari banyaknya etnis, bahasa, sosial, budaya, hingga agama. Fakta tersebut semakin menguat di Tana Toraja, kawasan eksotik di Sulawesi Selatan yang menyajikan kemajemukan budaya dan agama. Sudah menjadi hal biasa jika dalam satu keluarga terdapat agama yang berbeda, tetapi masih terikat dalam nilai Tongkonan. Tongkonan adalah rumah adat masyarakat Toraja, atapnya melengkung menyerupai perahu, terdiri atas susunan bambu. Rumah inilah yang menjadi simbol persatuan orang Toraja.

Agama dalam konteks apapun tidak dapat dipaksakan oleh manusia manapun kepada manusia lainnya. Jika Tuhan menghendaki semua manusia pasti tunduk, pasrah, dan beriman kepada Islam. Akan tetapi, pluralitas adalah sebuah fakta kehidupan yang harus disikapi dengan sikap pluralis yang tinggi. Allah Swt. memberikan isyarat dan sekaligus pesan universal terkait dengan pluralitas manusia, sebagaimana terdapat dalam QS. Yunus/10: 99.

"Dan jikalau Tuhanmu menghendaki, tentulah beriman semua orang yang di muka bumi seluruhnya. Maka apakah kamu (hendak) memaksa manusia supaya mereka menjadi orang-orang yang beriman semuanya?"

Melalui kerangka studi agama, pandangan seseorang terhadap komunitas lain yang berbeda keyakinan akan membentuk corak teologis menjadi tiga. Pertama, teologi apologis. Model teologi ini diimplementasikan dengan menyerang keyakinan agama lain untuk memperkokoh keyakinannya. Kedua, teologi dialogis. Model ini berupaya mencari perbedaan pandangan pada doktrin keagamaan masing-masing, memperhatikan kesesuaian yang memungkinkan terjadinya saling mengakui. Ketiga, teologi konvergensi. Pada level ini, pandangan teologis tidak lagi diarahkan pada perbedaan dalam doktrin agama tetapi mengedepankan substansi dan intisari ajaran agama yang diyakini sehingga memberikan ruang perjumpaan antar identitas yang berbeda (Mahmud, 2013). Sikap dan pandangan terhadap pluralitas biasanya disebut sikap pluralistik, yang sebagian kalangan memakai istilah pluralisme.

Memahami pluralisme di Indonesia secara sederhana dapat dilakukan secara komparatif dengan mengamati tumbuhnya budaya yang sangat beragam. Di Maluku terdapat budaya Pela-Gandong sebagai dasar perserikatan antara satu negeri di pulaupulau (Lokollo, 1997), di Bali muncul kebudayaan Subak dalam bidang irigasi pertanian, dan budaya gotong royong pada masyarakat Jawa. Di Tana Toraja Tongkonan adalah simbol lokal yang khas dan melingkupi siklus kehidupan manusia, mulai dari lahir sampai mati. Tongkonan merupakan 'kursi' dari nenek moyang yang dihormati. Salah satu keturunan dari sang penemu (the founders), kepala kelompok 
keluarga, memimpin 'Rumah' dan segala isinya. Dia bertanggungjawab untuk mengamati semua upacara, tak peduli apakah upacara tersebut besar atau kecil, dimana 'Rumah' (tongkonan) adalah pusat sosial dan religius bagi kelompok keluarga (Idrus, 2016).

Distingsi Tana Toraja dengan daerah lain dapat dipotret dari beberapa aspek. Pertama, secara sosiologis Tana Toraja memiliki karakteristik yang unik. Selain kuatnya budaya Aluk Todolo (secara harfiah, kebiasaan orang terdahulu) yang menjadi agama lokal, juga fakta kerukunan antar umat Islam, Protestan, Katolik, Hindu, Budha, dan Aluk Todolo, sampai saat ini masih dilestarikan, ketika dalam keluarga menganut agama yang berbeda. Kedua, secara akademis-paedagogis model pendidikan dalam keluarga yang dihimpit oleh tradisi dan agama yang berbeda, tentu akan menyesuaikan dengan pluralitas tersebut. Ketiga, secara politis umat Islam dan warga Muhammadiyah hidup dalam konteks yang berbeda dengan masyarakat yang hidup di lingkungan mayoritas muslim.

Orang Toraja menganut sistem kekerabatan bilateral. Sistem bilateral dapat diartikan sebagai sistem yang mengadopsi dua pihak, dalam kasus ini pihak ayah dan pihak ibu memiliki kedudukan yang sama pentingnya atau bisa juga tidak penting (Kurniawan \& Rudyansjah, 2017). Pemilihan dapat dilakukan berdasarkan kepentingan yang dinilai menguntungkan. Dengan kata lain, satu keluarga dapat memilih secara bebas untuk mengikuti garis keturunan ayah atau ibu, tergantung pertimbangan keluarga.

Negara memang menjamin setiap warga negara mempraktikkan agamanya masing-masing, tetapi negara juga membatasi jumlah agama yang diakui. Jika warga negara tidak berafiliasi pada salah satu agama yang diakui negara, maka dianggap melakukan pembangkangan. Dalam kerangka ini, keluarga memiliki posisi yang sangat strategis untuk melakukan intervensi terhadap pemahaman anggota keluarganya dalam memandang pluralitas, dengan pendekatan pendidikan informal yang menjadi fokusnya (Widiyanto, 2016). Selain itu, menurut Sukiyani \& Zamroni (2014: 58) keluarga pada hakikatnya merupakan wadah pembentukan pemahaman masing-masing anggotanya. Hal ini kemudian diperkuat oleh Fachrudin (2011: 4) menyatakan bahwa keluarga merupakan lingkungan pertama bagi setiap individu di mana ia berinteraksi. Dari interaksi dengan lingkungan pertama inilah individu memperoleh unsur-unsur dan ciri-ciri dasar daripada kepribadiannya. Secara internal, tuntunan tentang pentingnya eksistensi keluarga dalam pendidikan pada masyarakat plural dapat dirujuk dalam Khittah Muhammadiyah 1956 (Khittah Palembang) pada muktamar ke-33 tahun 1956 di Palembang. Khittah tersebut adalah sebagai perwujudan tekad kuat untuk membentuk rumah tangga bahagia menurut kemauan agama Islam dan mewujudkan pergaulan yang baik antara penghuninya satu dengan yang lain. Mengatur hidup dan kehidupan antara rumah tangga dan tetangganya sejak mulai lahir, perkawinan dan kematian sehingga akhirnya dapat mewujudkan masyarakat Islam (Muhammadiyah, 2012). 
Secara fungsional, keluarga memiliki dua fungsi yang esensial keluarga yakni pertama keluarga sebagai tempat sosialisasi yang utama bagi anak-anak dan tempat mereka dilahirkan dan kedua tempat stabilitas kepribadian remaja atau orang dewasa. Parsons memperkenalkan teori AGIL (Adaptation, Goal Attainment, Integration, dan Latency). Lebih lanjut, Parson membedakan antara empat struktur dalam masyarakat menurut fungsi sistem tindakan (AGIL) yang dilaksanakan masyarakat. Pertama, Adaptation (adaptasi). Pada tahap ini, sebuah sistem harus dapat mengatasi situasi eksternal yang gawat. Sistem harus dapat menyesuaikan diri dengan lingkungan, dan selanjutnya menyesuaikan lingkungan itu dengan kebutuhannya. Kedua, Goal Attainment (pencapaian tujuan). Fungsi ini sebuah sistem harus mendefinisikan dan mencapai tujuan utamanya. Ketiga, Integration (integrasi). Sebuah sistem harus mengatur antar hubungan bagian-bagian yang menjadi komponennya. Keempat, Latency (pemeliharaan pola). Artinya, sebuah sistem harus melengkapi, memelihara, dan memperbaiki baik motivasi individual maupun pola kultural yang menciptakan dan menopang inovasi (Ritzer \& Goodman, 2012).

Kajian ini secara teoretis dan praktis linier dengan menguatnya populisme agama yang membonceng isu-isu politik serta mengancam persatuan dan kesatuan bangsa, sehingga kebaruan ide tentang pluralitas bangsa harus selalu diperkuat. Fenomena Pemilu tahun 2019 menguras energi bangsa ini, karena menjurus pada terjadinya disintegrasi sosial masyarakat yang terbelah secara tajam pada dua kutub pendukung kandidat calon presiden. Bahkan, isunya sudah memasuki wilayah sensitif agama yang sangat rawan dimanfaatkan untuk memecah belah bangsa Indonesia. Pada wilayah pegunungan Tana Toraja, muncul manusia yang arif dalam menyikapi pluralitas budaya dan agama menjadi harmoni sosial, dan potensial disebarkan pada wilayah yang memiliki karakteristik yang sama di Indonesia.

Penelitian ini memiliki fokus kajian, yakni: (1) menemukan latar pluralitas sosial keagamaan pada keluarga Muhammadiyah berbasis multireligius; (2) model pendidikan keluarga pluralis berbasis multireligius; (3) perilaku sosial keagamaan pada keluarga Muhammadiyah Pluralis. Keluarga Muhammadiyah yang menjadi informan penelitian ini, adalah yang telah memiliki nomor baku Muhammadiyah. Anggota Muhammadiyah dapat dibagi menjadi tiga kelompok, yakni anggota Muhammadiyah, yaitu memiliki kartu tanda anggota Muhammadiyah; warga Muhammadiyah yang aktif terlibat dalam kegiatan Muhammadiyah, meskipun tidak memiliki kartu tanda anggota Muhammadiyah maupun menjabat di struktur organisasi; dan simpatisan Muhammadiyah, orang yang memiliki cara pandang dan praktik ibadah yang sama dengan tuntunan Muhammadiyah meski tidak terlibat aktif dalam kegiatan Muhammadiyah.

\section{METODOLOGI PENELITIAN}

Penelitian ini memiliki tiga fokus utama, yaitu: fokus pertama, latar pluralitas keluarga Muhammadiyah di Tana Toraja yang berbasis multireligius. Latar pluralitas yang berbasis multireligius dalam konteks penelitian ini adalah profil kemajemukan 
agama dan keyakinan yang terdapat dalam lingkup keluarga inti, seperti orang tua, saudara, mertua, dan anak. Fokus kedua, pola pendidikan keluarga yang diadaptasi dari McLeod dan Chaffee (2006), dapat diklasifikasi menjadi empat, yakni: protektif, pluralistik, dan konsensual. Fokus ketiga, perilaku sosial keagamaan keluarga Muhammadiyah di Tana Toraja. Jenis penelitian ini adalah kualitatif dengan pendekatan fenomenologi. Teknik pengumpulan data yang digunakan adalah observasi, wawancara mendalam (in-depth interview), dan dokumentasi. Data dianalisis secara kualitatif meliputi reduksi data, sajian data, dan penarikan kesimpulan. Dalam penelitian kualitatif peneliti merupakan instrument kunci (key instrument). Penetapan sumber data dilakukan dengan purposive sampling atau dengan pertimbangan tertentu. Pemilihan sekelompok subjek dalam purposive sampling, didasarkan atas ciri tertentu yang memiliki kaitan erat dengan karakteristik yang sudah diketahui sebelumnya, berdasarkan tujuan penelitian. Pengecekan keabsahan data menggunakan triangulasi, member check dan Focus Group Discussion (FGD) dengan kolega peneliti dan jaringan di Muhammadiyah.

\section{HASIL PENELITIAN DAN PEMBAHASAN}

Data yang disajikan dalam kajian ini bersumber dari lapangan (field research), sebanyak tujuh keluarga yang memiliki latar pluralistik sebagai unit analisis dan sumber data, kemudian dilanjutkan dengan pengayaan dari informan lain. Informan diobservasi, diwawancarai, dan diamati selama 6 (enam) bulan. Informan dalam penelitian ini dituliskan dengan inisial untuk menjaga kerahasiaan, informan adalah: (1) AMP (61 Tahun), adalah guru dan da'i Muhammadiyah di Ge'tengan Tana Toraja yang telah memiliki Nomor Baku Muhammadiyah. Terlahir dari pasangan Petrus Minggu dan Damaris Tappe adalah penganut Kristen Protestan yang taat, bahkan Petrus Minggu sampai saat ini tercatat sebagai anggota Majelis Gereja Pantekosta Lembang Simbuang; (2) DR (44 Tahun), Pimpinan Cabang Muhammadiyah Mengkendek dan ketua Yayasan Pembinaan Muallaf Tana Toraja. Lahir dari orang tua bernama Sempa Toyang dan Kristina, penganut Katolik yang taat di Sangalla Tana Toraja; (3) BA (30 tahun), Kepala SMK Pesantren Pembangunan Muhammadiyah Tana Toraja. Dilahirkan dari ayah Kristen dan Ibu Islam; (4) SP (40 Tahun) adalah diaspora dari tanah Jawa yang memiliki istri bernama Margareta. Margareta adalah aktifis Aisyiyah Mengkendek terlahir dari pasangan Y. Tatotetu dan Agustina Kappa seorang penganut Katolik; (5) SY (30 Tahun), aktivis Ikatan Pelajar Muhammadiyah Tana Toraja, istrinya seorang muallaf. Saat ini menetap di Rantetayo, dan satu-satunya keluarga muslim di daerah tersebut; (6) PW (46 Tahun), adalah aktivis dan Muballigh Aisyiyah di Bittuang, perbatasan Tana Toraja-Mamasa, ayahnya adalah aktivis Muhammadiyah sedangkan ibunya beragama Katolik; dan (7) PT (43 Tahun), Sekretaris Pimpinan Cabang Muhammadiyah Bongkakaradeng periode 2005-2010. Lahir dari ayah Kristen dan Ibu Aluk Todolo kemudian masuk Islam, dibesarkan oleh nenek penganut Aluk Todolo. Peneliti juga mewawancarai tokoh agama di Tana Toraja baik Islam maupun Kristen dan Katolik secara acak. Kegiatan wawancara dengan 
tokoh lintas agama untuk mendapatkan data sebagai pembanding sehingga terjaga objektivitasnya. Data lain yang bersifat sekunder dikumpulkan dari berbagai dokumen resmi persyarikatan Muhammadiyah, yaitu anggaran dasar dan anggaran rumah tangga Muhammadiyah, matan keyakinan dan cita-cita hidup Muhammadiyah, langkah 12 Muhammadiyah, khittah Muhammadiyah, pedoman hidup Islami, serta berbagai dokumen resmi yang termuat dalam berita resmi Muhammadiyah, dan hasil riset tentang Muhammadiyah.

\section{Pluralitas Keluarga Muhammadiyah Berbasis Multireligius}

Pluralitas pada keluarga Muhammadiyah berbasis multireligius terbentuk dari proses konversi agama. Terdapat faktor internal dan eksternal yang melatarbelakangi terjadinya konversi agama tersebut. Faktor internal terkait dengan pemaknaan dan kesadaran pribadi akan kebenaran Islam sebagai agama samawi terakhir, sedangkan faktor eksternal terkait dengan beberapa aspek tuntutan lingkungan, di antaranya adalah perkawinan. Perkawinan telah menyebabkan orang Toraja berpindah agama dari Protestan, Katolik, dan Aluk Todolo menjadi muslim, demikian juga sebaliknya.

Pada gambar 1 terlihat bahwa pluralitas keluarga Muhammadiyah berbasis multireligius terbangun karena adanya konversi agama dari Aluk Todolo, Protestan, Katolik menjadi muslim. Jika diidentifikasi, maka konversi agama terjadi karena dorongan dari dalam diri (endogenos origin), yaitu proses perubahan yang terjadi dalam diri seseorang atau kelompok. Sedangkan, konversi agama akibat unsur dari luar (exogenous origin), yaitu proses perubahan yang berasal dari luar diri sehingga mampu menguasai kesadaran orang atau kelompok yang bersangkutan.



Gambar 1. Latar Pluralitas Keluarga

Pada dasarnya, berbagai latar yang menyebabkan terjadinya multireligius pada keluarga Muhammadiyah, yaitu konversi atau pindah agama dan akulturasi agama, yang biasanya terjadi karena pernikahan yang tidak dibatasi oleh syarat pemeluk agama dalam keluarga. Artinya, konversi agama biasanya terjadi karena adanya 
persyaratan dari keluarga salah satu mempelai untuk menyamakan agamanya, sehingga konversi agama sendiri memiliki beberapa faktor penyebabnya, baik karena kesadaran yang ditemukan sendiri yang dalam agama biasa disebut 'hidayah' tanpa pengaruh lingkungan sosialnya, maupun faktor-faktor yang bersifat 'intervensi' karena ekonomi, pernikahan, kekerabatan, dan lain sebagainya.

Konversi agama tentu tidak mudah bagi seseorang, terutama bagi mereka yang tinggal dengan masyarakat bersosial tinggi, karena membutuhkan proses pertimbangan yang amat mendalam. Tetapi, fenomena yang menarik adalah karena seseorang rela meninggalkan keyakinannya pada agama sebelumnya, serta memutuskan untuk berpindah keyakinan agar sama dengan pasangannya. Jika hanya kesamaan agama yang diharapkan, maka setelah menikah biasanya tidak bersungguh sungguh dalam menerapkan nilai-nilai serta mendalami ajaran agama Islam dalam rumah tangga mereka. Namun, tidak semuanya mengalami peristiwa tersebut. Terdapat seorang mualaf termotivasi untuk memahami serta mengenal agama pasangannya lebih dalam sehingga terdorong untuk mempelajari agama tersebut.

\section{Pola Pendidikan dalam Keluarga Muhammadiyah Berbasis Multireligius}

Pola pendidikan dalam keluarga Muhammadiyah pluralistik berbasis multireligius menerapkan beberapa pola yang dipakai secara komplementer. Dari analisis, dengan meminjam modifikasi interaksi dan komunikasi yang dibuat oleh McLeod dan Chaffee (2006), pola pendidikan dalam keluarga memiliki peranan yang sangat besar dalam pembentukan kepribadian anak.

Pola pendidikan pada keluarga Muhammadiyah pluralis berbasis multireligius dapat dilihat pada gambar berikut ini.

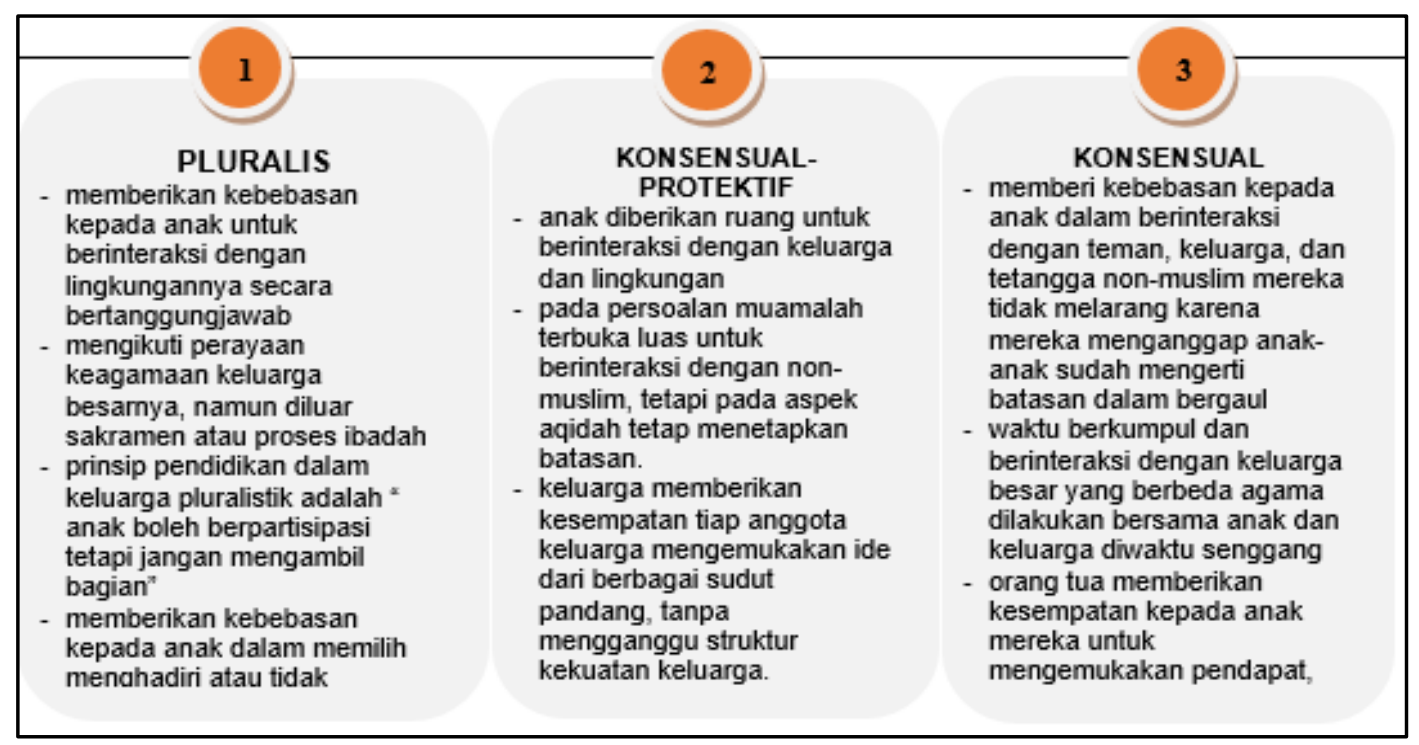

Gambar 2. Pola Pendidikan dalam Keluarga Muhammadiyah Berbasis Multireligius 
Pada gambar 2 tersebut dapat dijelaskan sebagai berikut. Pertama, terdapat tiga keluarga yang menerapkan pola pluralis dalam pendidikan di keluarga. Pada pola ini, keluarga menjalankan model interaksi yang terbuka dalam membahas ide dengan semua anggota keluarga, menghormati minat anggota lain dan saling mendukung. Kedua, terdapat dua keluarga yang menerapkan pola konsensual yang didefinisikan sebagai pola komunikasi dan interaksi yang berorientasi sosial maupun yang berorientasi konsep, serta setiap anggota keluarga mengemukakan ide dari berbagai sudut pandang, tanpa mengganggu struktur kekuatan keluarga, keputusan selalu diawali dengan musyawarah. Ketiga, terdapat dua keluarga menerapkan pola konsensual cenderung protektif. Pola konsensual diterapkan karena mereka berada dalam situasi yang plural berbasis multireligius, dan harus tetap eksis sebagai keluarga. Cenderung protektif, ditandai dengan rendahnya interaksi dalam orientasi konsep, tetapi tinggi dalam orientasi sosial, kepatuhan dan keselarasan sangat dipentingkan. Pola ini terdapat pada keluarga yang pernah mengalami ketegangan pada masa awal konversi agama, sehingga hal tersebut menjadi alasan untuk memproteksi secara terbatas anak-anak mereka. Konversi agama akan menyisakan pengalaman yang berbeda pada setiap keluarga, terlebih lagi jika keluarga tersebut memiliki keluarga besar yang kuat.

\section{Perilaku Sosial Keagamaan Keluarga Muhammadiyah}

Kurun waktu sepuluh tahun terakhir, hubungan komunikasi di bidang sosial keagamaan antara pemeluk agama khususnya Islam-Kristen di Tana Toraja tidak terjadi ketegangan dan pertentangan yang berarti, apalagi konflik terbuka seperti Ambon dan Poso, belum pernah terjadi. Konflik sosial keagamaan maupun ketegangan yang diakibatkan oleh perbedaan agama dapat dinetralisir oleh lembaga-lembaga keagamaan dan adat melalui dialog. Kota Makale ibu kota Tana Toraja merupakan sentral aktivitas dan dinamika yang ada di Tana Toraja, baik dari aspek sosial, ekonomi, politik, hukum, maupun budaya. Karenanya, keberhasilan lembaga-lembaga keagamaan dalam membangun dialog antar-agama dapat menciptakan kerukunan umat beragama di seluruh kabupaten dan kota yang ada dalam wilayah Provinsi Sulawesi Selatan.

Upaya membina kerukunan dalam kehidupan antar umat beragama di Tana Toraja sebenarnya juga dilakukan oleh Majelis Ulama Indonesia (MUI), Forum Komunikasi Umat Bergama (FKUB), Nahdlatul Ulama (NU), Muhammadiyah, Sinode Gereja Kristen Indonesia (GKI) sebagai struktur pimpinan tertinggi dalam organisasi Gereja, dan Keuskupan sebagai struktur organisasi tertinggi dalam agama Katolik. Salah satu organisasi kemasyarakatan yang berperan membina kerukunan antara umat beragama, khususnya antara Islam-Kristen adalah Muhammadiyah. Muhammadiyah melalui institusi keluarga mampu menampilkan wajah Islam sebagai agama damai dengan memperhatikan nilai adat masyarakat Tana Toraja. Muhammadiyah menjadi jembatan penghubung antara muslim dan non-muslim dalam rangka menciptakan kerukunan kehidupan umat beragama di Tana Toraja. 
Berbagai isu sensitif mampu dilalui oleh masyarakat Toraja, di antaranya yang menonjol adalah pendirian rumah ibadah. Masjid dan mushola di Tana Toraja bebas dan aman untuk didirikan, walaupun belum ada izinnya tetapi boleh berjalan sepanjang menjaga toleransi dengan umat lain di sekitarnya. Kami tidak pernah mengganggu atau menghambat proses pendirian rumah ibadah seperti masjid dan musholla, karena bagi orang Toraja, ibadah adalah hak bagi setiap agama.

Muhammadiyah di Tana Toraja memiliki pengalaman panjang dalam merespon pluralitas budaya dan agama. Selama ini, tokoh-tokoh Muhammadiyah, baik kaum tua maupun kaum muda, menunjukkan komitmen untuk menghadirkan wajah Islam moderat dan ramah terhadap keanekaragaman agama dan kultur. Selain melalui kiprah tokoh-tokoh Muhammadiyah, ikhtiar untuk membumikan dan mengakomodasi pluralitas pada amal usaha bidang pendidikan. Lembaga pendidikan Muhammadiyah mulai tingkat dasar, menengah, hingga pendidikan tinggi, telah dimaksimalkan perannya sebagai layanan publik untuk mendidik anak-anak bangsa dari berbagai etnis, golongan, dan agama. Kiprah Muhammadiyah di bidang pendidikan kian terasa di daerah-daerah yang berpenduduk minoritas Muslim.

Salah seorang muballigh Muhammadiyah, "DR" pendiri Yayasan Pembinaan Muallaf menuturkan "Jika muballigh radikal dalam menyampaikan Islam, maka berpotensi terjadi ketegangan antar umat beragama. Solusinya adalah mengambil jalan tengah, menjadikan budaya sebagai instrumen penting dalam berdakwah. Orang Toraja sangat royal dalam mengeluarkan hartanya baik untuk dirinya dan keluarga tanpa memandang perbedaan agama. Bagi sebagian orang Muhammadiyah, acara tersebut mubazir, bid'ah, bahkan haram dilakukan karena tidak ada satupun ayat dan hadis yang memerintahkannya. Akan tetapi, semangat pengorbanan orang Toraja tersebut tidak boleh dimatikan, namun dapat dikanalisasi dalam bentuk jihad bil amwal, mengorbankan harta benda untuk keperluan dakwah"

Fakta koeksistensi keagamaan muslim dan non-muslim lainnya terdapat di kampung Ke'pe Tinoring kecamatan Mengkendek. Di kampung tersebut terdapat Masjid Nurul Muallaf binaan "AMP" dan istrinya "KR", berhadapan langsung dengan bangunan yang cukup megah, gereja Santo Petrus. Keberadaan masjid Nurul Muallaf di daerah yang mayoritas non-muslim tersebut memiliki cita rasa esoterik yang tinggi. Betapa tidak, pembangunan masjid dimotori oleh tokoh-tokoh Islam dan non-muslim bersama masyarakat, karena jumlah umat Islam saat itu hanya 12 (dua belas) kepala keluarga.

Sampai saat ini masjid tersebut selain dimanfaatkan untuk kegiatan rutin ibadah umat Islam, juga sebagai tempat pendidikan anak-anak muslim di sekitar daerah tersebut. Dalam aktivitas keagamaan seperti Maulid Nabi di masjid, maka diselipkan acara silaturahim di luar masjid yang melibatkan seluruh umat Islam dengan warga yang beragama Nasrani maupun Aluk Todolo. Non-muslim di undang dalam kegiatan Maulid Nabi dan Isra' Mi'raj bukan untuk didoktrin atau dimurtadkan, tetapi menjalin silaturahim dengan umat Islam. Di luar masjid disiapkan tenda untuk warga muslim dan non-muslim bersilaturahim, sesudah acara keagamaan selesai. Semua penduduk 
di sekitar masjid ini beragama non-Muslim, tetapi masjid dalam keadaan aman, tidak ada gangguan sedikitpun, termasuk penyelenggaraan shalat/ibadah.

Pengalaman "MG" memiliki orang tua yang berbeda agama tidak menjadi halangan untuk merajut benang silaturahim. Momen hari besar keagamaan seperti Idul Fitri dan Natal selalu dimanfaatkan untuk menunjukkan kepedulian satu dengan yang lainnya. Pada saat perayaan hari besar Islam, maka keluarga besarnya yang Nasrani menyisihkan waktu dan tenaga untuk membantu persiapannya seperti memasak makanan, dan lain sebagainya. Demikian juga sebaliknya, jika keluarga besarnya yang Nasrani merayakan Natal, maka "MG" membantu menyiapkan makanan dan minuman untuk keluarga besarnya. Kondisi ini bertahan sampai dengan saat ini dalam suasana rukun dan damai dalam perbedaan.

Pengalaman pluralitas bebrbasis multireligius juga ditunjukkan oleh "PW", muballigh Aisyiyah di kecamatan Bittuang, perbatasan Tana Toraja-Mamasa. Selain sebagai lokomotif pembauran masyarakat muslim dan non-muslim dalam setiap perayaan keagamaan, Patmawati juga menunjukkan kemampuan dalam melakukan pendekatan pada beberapa non-muslim agar dapat hidup rukun berdampingan. Saat ini, masyarakat Lembang Paku di Kecamatan Bittuang Tengah menyelesaikan pembangunan masjid Nurul Hikma yang diinisiasi oleh Patmawati dan umat Islam di daerah tersebut, tetapi ketua pembangunannya adalah seorang pendeta yang mengerahkan jemaatnya untuk membantu tenaga, moril dan materil.

Pada setiap momen lebaran Idul Fitri yang biasanya dirayakan di masjid raya Makale selalu dihadiri pejabat setempat. Tradisi perayaan lebaran di Toraja selalu dihadiri Bupati yang beragama Nasrani untuk menyambut Idul Fitri Bupati biasanya membawa serta pejabat daerah dan tokoh agama untuk menunjukkan keseriusannya dalam menjaga pluralitas dan keharmonisan Tana Toraja yang telah mendunia. Momen tersebut biasanya ditutup dengan saling berjabat tangan dan makan bersama sebagai luapan kegembiraan dalam suasana Idul Fitri. Jika di beberapa daerah Idul Fitri hanya dirayakan oleh umat Islam saja, tetapi di Toraja Idul Fitri menjadi simbol kemenangan bersama yang dibingkai dalam kemajemukan. Implikasi lain bidang sosial keagamaan tercipta pada hari raya Idul Adha, ketika dilakukan penyembelihan hewan qurban, khususnya di kampung Minanga Tana Toraja. Semangat orang Toraja mengurbankan hewan berupa kerbau tidak hanya dilakukan pada upacara adat Rambu Solo atau Rambu Tuka', tetapi pada saat Idul Adha fenomena mencairnya hubungan muslim dan non-muslim sangat terasa. Penyembelihan hewan qurban di kediaman salah satu tokoh Muhammadiyah di kampung Minanga tidak hanya dihadiri dan dilakukan oleh muslim, tetapi non-muslim juga membantu dan ikut mendapat bagian daging dari hewan sembelih tersebut.

Kerukunan dan toleransi juga ditunjukkan secara internal oleh Muhammadiyah dan Nahdatul Ulama sebagai ormas Islam yang cukup eksis di Tana Toraja. Dilihat dari pengamalan ibadahnya, Nahdliyin dan Muhammadiyah memiliki pengikut yang cukup berimbang. Ketika terjadi perbedaan hari raya seperti hari raya kurban beberapa tahun sebelumnya, kedua ormas Islam tersebut saling menghormati. Bahkan Pengurus 
Cabang Nahdlatul Ulama (PC.NU), Kabupaten Tana Toraja masa Hikmad 2014-2019, dilantik oleh Pengurus Wilayah NU Sulawesi Selatan di Gedung Pusat Dakwah Muhammadiyah (PUSDAM) Makale Tana Toraja. Acara ini sempat menjadi headline pada koran lokal dan nasional sebagai potret kerukunan internal umat Islam. Pemanfaatan gedung Pusat Dakwah Muhammadiyah Tana Toraja oleh Nahdlatul Ulama dan ormas Islam lainnya bukan untuk pertama kalinya, Muhammadiyah dan komunitas Islam lainnya di Tana Toraja mengadakan perayaan hari besar Islam bersama-sama di gedung tersebut.

Hasil penelitian menunjukkan, secara kualitatif terdapat kaitan yang erat antara pendidikan keluarga dan perilaku sosial keagamaan. Pertautan antara pendidikan keluarga pluralis bebrbasis multireligius merupakan solusi atas realitas budaya dan agama yang beragam sebagai sebuah proses pengembangan seluruh potensi manusia Indonesia yang menghargai pluralitas dan heterogenitas sebagai konsekwensi keragaman budaya, etnis, suku dan aliran atau agama (Maslikhah, 2007).

Pluralitas bangsa Indonesia semakin memperkuat keharusan untuk menempatkan pendidikan berwawasan Pluralitas dan Multikultural sebagai nafas dan karakter (Yaqin, 2005). Keberagaman budaya di Indonesia merupakan kenyataan historis dan sosial yang tidak dapat disangkal oleh siapapun. Keunikan budaya yang beragam tersebut memberikan implikasi pola pikir, tingkah laku dan karakter pribadi masing- masing sebagai sebuah tradisi yang hidup dalam masyarakat dan daerah. Tradisi yang terbentuk akan berlainan dari satu suku/ daerah dengan suku/daerah yang lain (Ibrahim, 2013).

Berdasarkan fakta penelitian ini, keluarga yang masuk dalam tipologi Muhammadiyah Pluralis melakukan konvergensi sosial keagamaan dengan kelompok lain yang berbeda budaya dan agama, sehingga mereka memiliki inklusivitas orientasi sosial. Ruang perjumpaan mereka memiliki radius yang sangat luas dan kompleks dalam bidang sosial keagamaan, pendidikan, ekonomi, dan politik. Tindakan orangorang Muhammadiyah yang dikenal sebagai muslim puritan ternyata sangat akomodatif bahkan masih terlibat dalam tradisi lokal dan berpartisipasi pada perayaan keagamaan. Sikap warga Muhammadiyah yang terbuka, toleran, dan akomodatif membuat masyarakat tidak menaruh kecurigaan apalagi membangun permusuhan dengan Muhammadiyah. Kehadiran Muhammadiyah sebagai "minoritas kreatif" yang pluralis membuat masyarakat menerima bahkan mendukung dan ikut ambil bagian dalam berbagai kegiatan yang dimotori Muhammadiyah, meskipun mereka tidak menjadi anggota formal Muhammadiyah.

\section{SIMPULAN}

Pluralitas sosial keagamaan pada keluarga Muhammadiyah berbasis multireligius di Tana Toraja dibentuk oleh faktor budaya dan agama. Konversi agama dari non-muslim menjadi muslim yang terjadi dalam keluarga Muhammadiyah melalui dua unsur dan model, yakni kesadaran pribadi (endogenos origin), yaitu proses perubahan yang terjadi dalam diri seseorang atau kelompok, dan dorongan dari luar 
(exogenous origin), yaitu proses perubahan yang berasal dari luar diri karena perkawinan. Pendidikan keluarga Muhammadiyah pluralis yang berbasis multireligius di Tana Toraja berlangsung dalam beberapa model, yakni pluralis, protektif, dan konsensual cenderung protektif. Perilaku sosial keberagamaan diidentifikasi terjadi pada ranah sosial keagamaan, pendidikan formal, politik, dan ekonomi. Fakta koeksistensi budaya dan keagamaan yang ditimbulkan dari pola pendidikan dalam keluarga yang mengedepankan nilai pluralis dan multikulturalisme, pola pendidikan serupa dapat diterapkan pada wilayah yang memiliki karakteristik sama dengan Tana Toraja.

\section{DAFTAR PUSTAKA}

Fachrudin. (2011). Peranan Pendidikan Agama dalam Keluarga Terhadap Pembentukan Kepribadian Anak-anak. Jurnal Pendidikan Agama Islam -Ta'lim, 9(1), 1-16. Retrieved from http://jurnal. upi.edu/file/01_Peranan_ Pendidikan_Agama_dalam_Keluarga_-_Fahrudin.pdf

Ibrahim, R. (2013). Pendidikan Multikultural : Pengertian, Prinsip, dan Relevansinya dengan Tujuan Pendidikan Islam. ADDIN, 7(1), 129-154. Retrieved from https://media.neliti.com/media/publications/54545-ID-pendidikan multikul

tural-pengertian-prin.pdf

Idrus, N. I. (2016). Mana' dan Éanan: Tongkonan, Harta Tongkonan, Harta Warisan, dan Kontribusi Ritual di Masyarakat Toraja. ETNOSIA Jurnal Etnografi Indonesia, 1(2). Retrieved from http://journal.unhas.ac.id/index.php/etnosia/

article/view/1612/911

Kurniawan, A., \& Rudyansjah, T. (2017). Kajian Mengenai Perubahan Afiliasi pada Sistem Organisasi Sosial Masyarakat Lematang. Jurnal Antropologi: Isu-Isu Sosial Budaya, 18(2), 89-103. Retrieved from http://jurnalantropologi. fisip.unand .ac.id/index.php/jantro/article/view/60/55

Lokollo, J. (1997). Seri Budaya Pela-Gandong dari Pulau Ambon. Ambon: Lembaga Kebudayaan Daerah Maluku.

Mahmud, N. (2013). Lembaga Kebudayaan Daerah Maluku. Kudus: Maseifa Jendela Ilmu.

Maliki, Z. (2010). Pluralisme Agama: Pergulatan Dialogis Islam-Kristen di Indonesia. Malang: UIN-Maliki Press.

Maslikhah. (2007). Quo Vadis Pendidikan Multikultural: Rekonstruksi Sistem Pendidikan berbasis Kebangsaan. Surabaya: JP Books.

Muhammadiyah, P. P. (2012). Pluralisme Agama: Pergulatan Dialogis Islam-Kristen di Indonesia. Yogyakarta: Suara Muhammadiyah.

Ritzer, G., \& Goodman, D. J. (2012). Teori Sosiologi Modern. Jakarta: Kenanga.

Sukiyani, F., \& Zamroni. (2014). Pendidikan Karakter dalam Lingkungan Keluarga. SOCIA: Jurnal Ilmu-Ilmu Sosial, 11(1), 57-70.

Widiyanto, A. (2016). Religious Authority and the Prospects for Religious Pluralism in Indonesia. Zurich: The Deutsche Nationalbibliothek Lit Verlag GmbH \& Co. KG Wien. 
Yaqin, M. A. (2005). Pendidikan Multikultural: Cross-Cultural Understanding untuk Demokrasi dan Keadilan. Yogyakarta: Pilar Media.

Zada, H. (2006). Agama dan Etnis: Tantangan Pluralis Nilai-nilai Pluralisme dalam Islam. Jakarta: Nuansa-Fatayat NU-Ford Foundation. 